\title{
Does the Taste and Appearance of Food Affect Food Waste in Low-Salt Diet Patients?
}

\author{
SUMARTO $^{1,2}$ and Marianawati SARAGIH ${ }^{1}$ \\ ${ }^{1}$ Department of Nutrition, Poltekkes Kemenkes Tasikmalaya, Indonesia \\ ${ }^{2}$ Health and Disaster Emergency (HADE) Center, Center of Excellent Poltekkes \\ Kemenkes Tasikmalaya, Indonesia \\ (Received June 19, 2019)
}

\begin{abstract}
Summary Large of food waste can be one indicator of nutritional deficiencies in patients. This lack of nutrition is a factor that can increase morbidity, length of stay and cost of care. The acceptance of the taste of food in patients with low-salt diets is often a problem. This study aimed to assess the effect of taste and appearance of foods on food waste in patients with low-salt diets. The study was a cross-sectional design with observational methods. Data was collection from interview using questionnaire. The study was conducted at the Jasa Kartini (JK) Hospital, Tasikmalaya in August-October 2017. Subjects $(n=30)$ were patients in low-salt diet. The acceptance of the taste and appearance of food from JK Hospital according to the respondents, the value was quite varied, generally above the median value on a scale of $1-3$. The average of food waste from patients with low-salt diets at JK Hospital was still above the PGRS (Nutritional Guideline for Hospital) standard 2013, which was $26 \%$. Based on the analysis between variables, there was a significant relationship between food waste and food taste $(p=0.002)$ and food waste and food appearance $(p=0.000)$ in low-salt diets patients. The taste and appearance of food significantly affect the food waste in low-salt diet patients.
\end{abstract}

Key Words taste of food, appearance of food, low-salt diet, food waste

Some surveys in hospitals showed that the incidence of hospital malnutrition was due to inappropriate nutrition services. Inpatient nutrition services include several aspects conducted itiretively, such as nutritional assessment, nutritional diagnosis, nutritional interventions (such as food planning, food provision, education/ counseling), and nutritional counseling, and monitoring and evaluating (1).

One of the functions of hospitals, especially the nutrition unit, is to carry out food service. Food service is a series of activities ranging from menu planning to distribution of food to consumers, in order to achieve optimum health status through the provision of the correct diet, including recording, reporting and evaluation activities. Food service at the hospital is aimed to provide good quality food in quantities according to the nutritional needs of patients (2).

One indicator of the quality of food given by the hospital is the patient's food intake. Patient's acceptance of the food served can be seen from the food waste. Patient's acceptability can be influenced by several factors including the quality of food and the quality of eating utensils. Food quality can be seen from the appearance of food and the taste of food. The use and selection of the right eating utensils can affect the appearance of food and it were affected by grade of room and variety of menus (3). Lack of nutrition in patients can be a factor that can increase morbidity, length of stay and cost

E-mail: sumarto@dosen.poltekkestasikmalaya.ac.id of care. Acceptance of food by the patients is commonly used as a measure of hospital food organization (4).

Based on the results of several studies, there were big proportion of food wasted in many hospitals. For example, inpatients from dr. Soeratno Hospital Gemolong, Sragen, Indonesia showed a food waste of $26.6 \%$ (5). Using the Comstock method, $18 \%$ of the vegetables served in Dr. Kariadi Hospital, Semarang, Central Java, Indonesia had food waste of $>75 \%$ (6). Based on research at Jasa Kartini Hospital, Tasikmalaya, West Java, Indonesia, the proportion of food waste was $37 \%(7)$; much higher than the maximum food waste of $20 \%$ (1). Among diabetes mellitus (DM) patients in Dr. M. Ashari Hospital, Indonesia, the amount of food waste was $59 \%$, which include rice, porridge, animal side dishes, vegetable dishes and vegetables (8). The causes of food waste in DM diet patients were eating schedules, food from outside the hospital, food taste and eating habits.

Another type of patients with high occurrence of food waste was among patients with low-salt diet. Many studies have shown that excessive sodium consumption can interfere with health $(9,10)$. High consumption of salt causes blood pressure to rise. Reducing salt consumption can reduce the risk of cardiovascular diseases such as heart failure and chronic kidney disease (11). On the other hand, salt provides a salty flavor that can increase appetite. Patients prescribed on low-salt diet were commonly those who suffered from kidney disease, hypertension, diabetes mellitus, and heart disease. This study aimed to assess the relationship between the 
acceptability of taste and appearance of foods served for patients with low-salt diets and food waste in a hospital in the Tasikmalaya city.

\section{MATERIALS AND METHODS}

This study used a cross-sectional design. Data was collected by interview using a questionnaire and by observation. The study was conducted at Jasa Kartini Hospital in Tasikmalaya city in May-September 2017.

The population in this study were all inpatients in the internal medicine room who were willing to take part in the research activities. From the total population, purposive sampling was chosen according to the specified inclusion and exclusion criteria.

Inclusion Criteria: Patients with a low-salt diet, patients have been treated for at least $1 \mathrm{~d}$ in class 1,2 or 3 inpatients, patients can be interviewed or represented and approved by the patient's family, patient is willing to be a respondent. Exclusion Criteria: The condition of the patient is critical, so data collection is difficult; upon hospital policy, data collection is not permitted for certain patients, for example, those treated in the VIP room. The calculation formula for the research sample is as follows:

$$
n=\frac{Z^{2}{ }_{1-\alpha / 2} P(1-P)}{d^{2}}
$$

The sample chosen was a patient with low-salt diet with the prevalence in the hospital in the study site was 8.5\% in February 2017. By using the formula above, the number of samples was 30 respondents with 10\% precision and a $95 \%$ confidence level.

The data used were primary data and secondary data. Primary data was obtained through direct observation, interviews with the help of questionnaires, and weighing. Primary data includes subject characteristics and patient acceptance of the menu presented by the hospital, and food waste. Secondary data includes menu cycle data and food lists in one menu cycle.

The primary data that has been obtained was then analyzed statistically. Data analysis used Microsoft Excell 2010 computer program and statistical software.

Food acceptance was categorized based on much likes, likes, and dislikes. Food waste variables were calculated as the percent of food leftovers using the formula:

Food waste $(\%)=\frac{\text { Food left over }(\mathrm{g})}{\text { Hospital portion standards }(\mathrm{g})} \times 100 \%$

Descriptive analysis was expressed as a percentage and the average consists of data on the characteristics of respondents (sex, age, and length of stay). Analysis of inferential using the correlation test. Correlation test used was the Spearman or Pearson correlation test to determine the relationship between the acceptability of the taste and the appearance of food on food waste.

This research has received a certificate of ethical clearance from the Health Research Ethics Commission of the Health Polytechnic of Bandung. Certificate number 08/KEPK/PE/VIII/2017 on August 7, 2017.

\section{RESULTS}

The respondents who were the subjects of this study were 30 patients. This amount has fulfilled the specified inclusion and exclusion criteria. Data collection was carried out on 10, 16 and 23 October 2017. The complete characteristics of the respondents is presented in Table 1.

The Acceptance of Food Taste and Appearance

Figure 1 presente the general acceptance on the taste and appearance of food based on food category. The average value was above 2 , showeing that generally the

Table 1. Characteristic of respondent and food waste.

\begin{tabular}{llc}
\hline No. & \multicolumn{1}{c}{ Characteristic } & Amount \\
\hline 1. Sex & 14 \\
& Man & 16 \\
& $\quad$ Women & $31-81 \mathrm{y}$ \\
2. & Age & $2-10 \mathrm{~d}$ \\
3. Length of stay & $74 \%$ \\
4. $\quad$ Food waste & $13 \mathrm{man}$ \\
& Average of food waste \\
& Number of respondents with food waste \\
& $>20 \%$ & \\
\hline
\end{tabular}

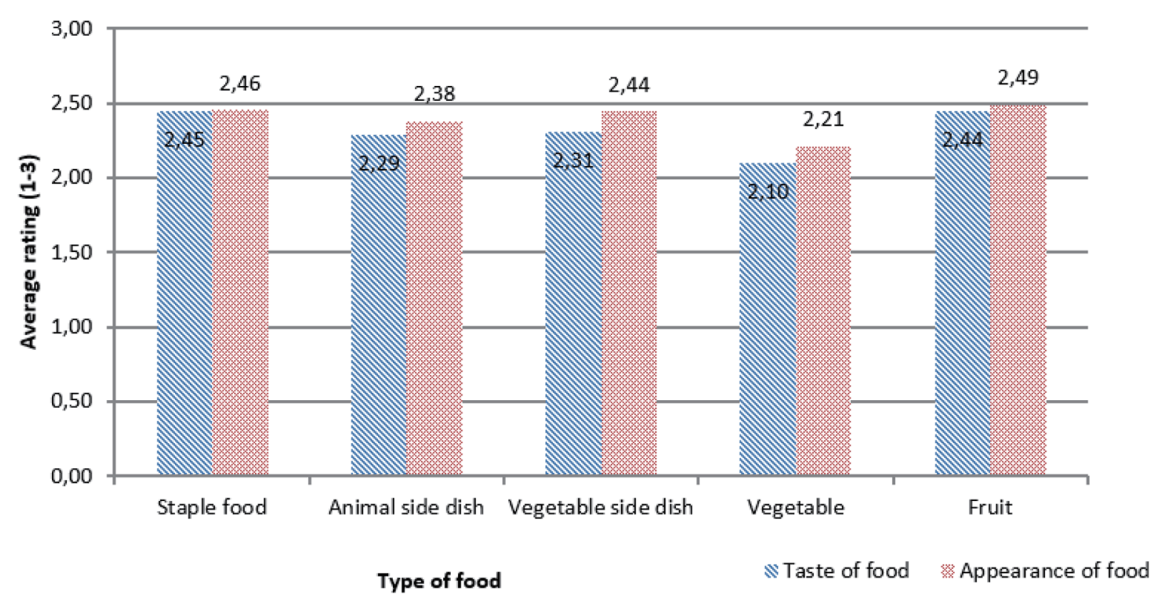

Fig. 1. Average Rating (Acceptance) of Low-Salt Diet Respondents on Appearance and Taste Per Type of Food at A Hospital. 
Table 2. Average of food waste from respondents of low-salt diets per type of food.

\begin{tabular}{lc}
\hline \multicolumn{1}{c}{ Type of food } & Average of food waste (\%) \\
\hline Staple food & 39 \\
Animal side dishes & 24 \\
Vegetable side dishes & 29 \\
Vegetable & 34 \\
Fruits & 5 \\
\hline Total (Average) & 26 \\
\hline
\end{tabular}

Table 3. Relationship between taste and appearance acceptance with food waste in low-salt diet respondents.

\begin{tabular}{|c|c|c|}
\hline \multirow{2}{*}{$\begin{array}{c}\text { Dependent } \\
\text { variable }\end{array}$} & \multicolumn{2}{|c|}{$\begin{array}{l}p \text { value of independent variable } \\
\text { (Spearman test) }\end{array}$} \\
\hline & Taste & Appearance \\
\hline Food waste & $\begin{array}{c}0.002 \\
(r=-0.548)\end{array}$ & $\begin{array}{c}0.000 \\
(r=-0.673)\end{array}$ \\
\hline
\end{tabular}

food received good acceptance from the subjects.

The taste acceptance rating was generally lower than the appearance acceptance for all types of food (staple food, animal side dishes, vegetable side dishes, vegetable, and fruit dishes). The lowest acceptance of both the taste and appearance was in the type of vegetable food. This can be understood because the food given was for low-salt diet. So, some patients feel a lack of taste in the food provided.

Food Waste

Although the acceptance was relatively good (Table 2 ), the amount of food was was still above the standard of Indonesian Hospital Nutrition Guidelines (1), which is a maximum of $20 \%$. In general, the average food waste was $26 \%$. The largest food waste was staple food, followed by vegetables, vegetable side dishes, animal side dishes, and fruits being the least.

Relationship between Variables

Table 3 shows that there was a relationship between food waste and acceptability of taste ( $p$-value $=0.002$ ) and appearance $(p$-value $=0.000)$. Factors that affect food waste consist of internal and external factors. Based on Table 3. external factors of acceptance (taste and appearance) affect the food waste from respondents with a low-salt diet.

In addition, internal factors also affect food waste in patients, such as the physical and psychological conditions of the patient. The physical condition of patients affecting food waste is presented in Table 4. The Table shows that the condition of patients who were postoperative and/or diagnosed with cholic appetite was low, so the food waste was the highest.

\section{DISCUSSION}

\section{Characteristic of Respondents}

The characteristics of the respondents in this study were in accordance with the characteristics of the population. The distribution of male and female was almost balanced, namely $14(46.67 \%)$ male and 16 female $(63.33 \%)$. Age of respondents also varies between 31-81 y, meaning that all respondents were included in the adult category. The length of stay was $2-10 \mathrm{~d}$. There were 13 people out of 30 respondents with food waste over than $20 \%$.

The characteristics of the respondents in this study were similar to those in Raden Mattaher Hospital Jambi (12). In the study, there were $32.6 \%$ men and $67.4 \%$ women; the age of respondents was 16 to over $64 \mathrm{y}$; respondents with a length of stay $>9 \mathrm{~d}$ was $12 \%$, and respondents with a length of stay $<9 \mathrm{~d}$ was $88 \%$. The results of this study indicate that food waste from animal-based foods and fruit were associated with length of stay (12).

All respondents in this study were patients with a low-salt diet. Salt intake was related to sodium intake in patients. Various diseases experienced by respondents in this study include hypertension and kidney failure. Low-salt diets and attention to the intake of sodium and potassium ratios have been shown to reduce blood pressure for non-hypertensive patients (13). The same thing happened in patients in a general hospital in Japan who showed that salt intake was related to blood pressure (14). Even recent research involving 12,126 subjects also shows that there was a relationship between salt intake and damage to liver function in the community (15).

The Acceptance of Food Taste and Appearance

Patient's acceptance of taste and appearance of food was assessed using a scale of 1-3. For all types of food (staple food, animal side dishes, vegetable side dishes, vegetables, and fruit), the acceptance of taste was lower than that of appearance. The average rating of acceptance of taste and appearance were still above 2, meaning that in general respondents have good acceptability on taste and appearance of foods at the hospital.

The results of this study were different from the results of research conducted in Prof. Dr. R. D. Kandou Hospital, Manado, Indonesia which shows low acceptance of animal and vegetable side dishes (16). Another study among VIP patients at the Regional General Hospital of Southeast Sulawesi Province, Indonesia showed that the acceptance of appearance and taste had an effect on patient satisfaction (17). Research at Sunan Kalijaga Hospital, Demak, Indonesia showed that the higher the satisfaction of food services at the hospital, the higher the energy and protein intake and the smaller the decline in nutritional status (12). Reducing the amount of salt in the patient's diet results in a change in the taste of the food, so that the acceptance of the food's taste is also lower.

Interventions in reducing sodium intake must be carried out at the community level, for example hospitals. 


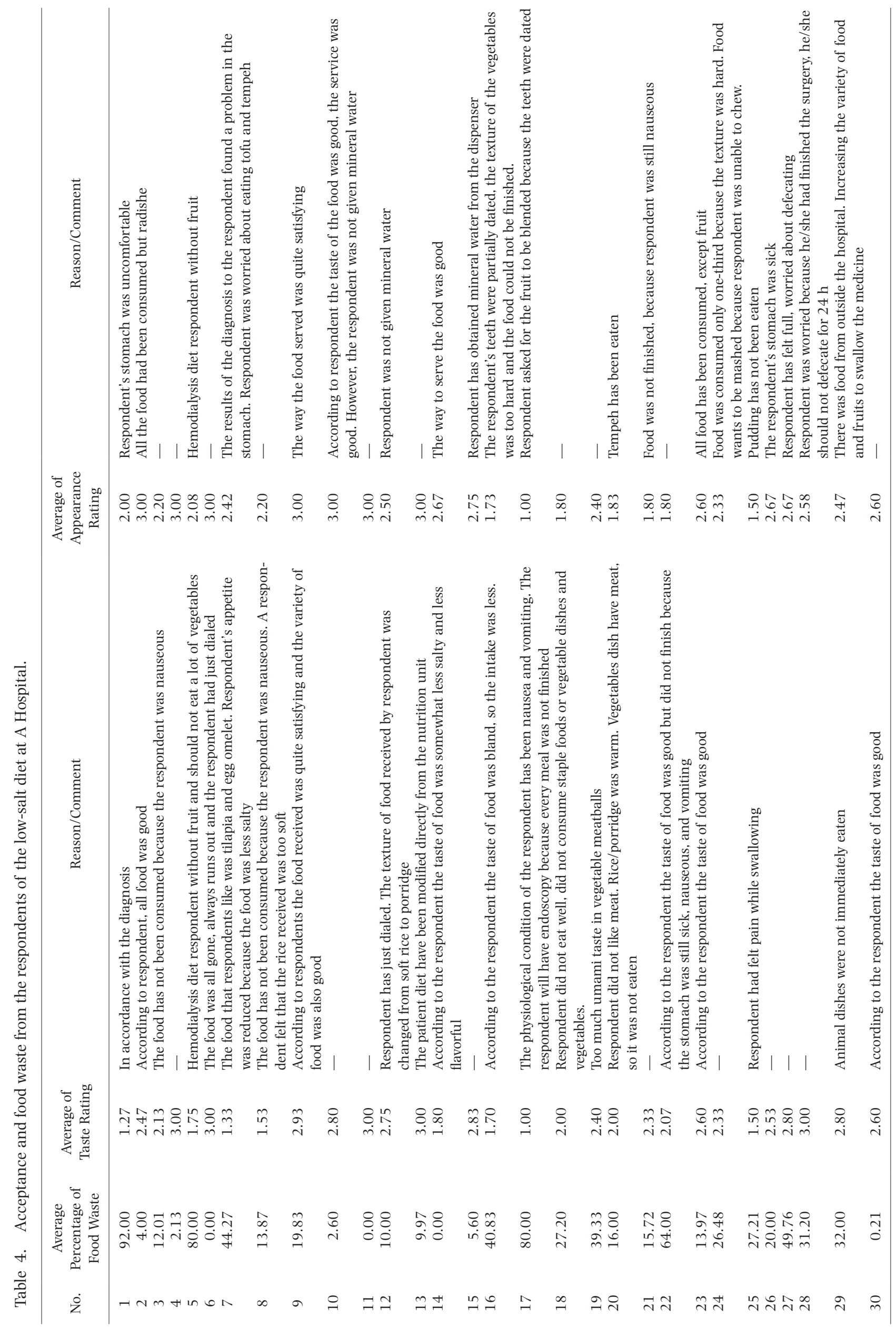


Intervention at the community level can significantly reduce sodium intake (18). That is, the provision of food in hospitals will be effective in regulating the pattern of excessive sodium consumption, especially in patients with a low-salt diet.

One way to increase the taste of food of low sodium foods is by modifying the type of salt or flavoring. One type of salt that has been developed was monomagnesium di-L-glutamate. This salt or flavoring has been successfully tested and can be used as a long-term strategy for consumption in patients with restricted sodium intake (19).

In addition, in Tibet, China has also developed low sodium and high potassium substitution salts. The results show that the salt was effective for lowering blood pressure, and was low-cost monitoring of hypertension (20). The program to reduce sodium intake needs to be done through collaboration between the food industry, health institutions or services, and the government (11).

Food Waste

The results showed that the average food waste was still high at $26 \%$. The result was still above the maximum standard for food waste, which is $20 \%$ (1). The food waste was highest in staple and vegetable foods, which were $39 \%$ and $34 \%$ respectively. The lowest remaining food in fruits was 5\%.

The results of this study were similar to studies on food waste carried out at Islamic Hospital in Jemursari, Surabaya at 2017 (21). The average percentage of food waste at the hospital was $25.1 \%$. The food waste from vegetable group was $34.3 \%$ and from rice was $31.7 \%$.

One hospital, Holistic Haospital Purwarkat have changed the standard portion to reduce food waste, yet the average of food waste was still at $27.6 \%$, above the standar of $20 \%$ (22). Research in the Dr. Tadjuddin Chalid hospital Makassar and Makassar City Hospital showed that food waste was still 30.9\% (23).

Food waste also occurs in hospitals abroad, as happened in Iran. Research conducted in two hospitals in Iran showed that the number of patients who had food waste in Qaem Hospital and Imam Reza Hospital was $27.84 \%$ and $22 \%$. Food waste in the appetizer was significantly higher than the main course (24).

The results of the study show that the leftovers from staple foods (rice) was still very high. One solution that can be given is to reduce the portion of rice on the patient's diet. This intervention has resulted in a significant reduction in leftovers in patients at Holistic Hospital, Purwakarta, Indonesia (22). Another way that can be done to reduce food waste was to provide a choice menu. Although the remaining food was still quite high, the effort to provide a choice menu can significantly reduce the remaining food of animal, vegetable and fruit dishes compared to the standard menu in the patient diet in Southeast Sulawesi General Hospital, Indonesia (17).

\section{Relationship between variable}

Based on Table 3, the results of the study show that there was a significant relationship between food waste and the acceptance of taste $(p$-value $=0.002)$ and appearance $(p$-value $=0.000)$. The results of this study were in accordance with the results of research at the Southeast Sulawesi Provincial Public Hospital which states that there was a significant influence on the appearance variable type (color, shape, and portion), taste (temperature, aroma, and maturity) of food served to the level of satisfaction of inpatients VIP. However, there was no significant effect on the appearance variables, namely the type of food texture presented to the satisfaction level of VIP inpatients (17).

The relationship between acceptance of taste and food waste/nutrient intake has also been carried out for Pemali Bangka Belitung High School 1 student (26). The Spearman correlation test showed that the level of preference for food taste had a significant relationship with the level of adequacy of energy and protein $(p<$ 0.05). The level of preference for food temperature was significantly related to the level of adequacy of phosphorus $(p<0.05)$. The level of preference for food temperature has a significant relationship with the level of energy and iron intake $(p<0.05)$. However, study among hospitalized patients at Islamic Hospital Jemursari, Surabaya, Indonesia did not show significant relationship between the appearance of food and food waste (21).

In detail, the causes of large food waste in patients with a low-salt diet can be seen in Table 4 . The results of this study indicate that internal and external factors affect food waste. Internal factors that can be seen from this study were the type of disease and the condition of the patient (2), such as postoperative conditions, so the stomach was still feeling nauseous. In addition, eating habits at home that was different from the menu served at the hospital also causes low acceptance and increases food waste.

The results also showed that some respondents commented that the food was tasteless. This was very reasonable because the food given was low salt diet. This also results in high residual food in these patients. Alternative solutions that can be given is to replace the low sodium salt and high potassium or substitute with magnesium so that the food still has a taste that is preferred by hypertensive patients or with low sodium diet.

In addition to a number of comprehensive solutions described earlier, other ways that can be given to reduce food waste and increase nutrient intake and fulfill the nutritional needs of patients with low-salt diet are through individual counseling. Individual counseling will be able to find out the specific constraints and food requirements of patients treated in the hospital. This has been proven from the results of research in hospital patients in Iran, namely feeding patients according to their needs and conditions can reduce the occurrence of food waste (24). The results of other researchers' review indicate that it provides clear evidence of the hospital/care home setting (27). This also needs to be considered in feeding in patients with a low-salt diet. 
Disclosure of state of $\mathrm{COI}$

No conflicts of interest to be declared.

\section{Acknowledgments}

The authors are thankful to the Potekkes Kemenkes Tasikmalaya (Health Polytechnic of Tasikmalaya), Ministry of Health RI for providing the research. In particular, we also say to the Department of Nutrition, Poltekkes Kemenkes Tasikmalaya and the Nutrition Unit of Jasa Kartini Hospital, Tasikmalaya City as a research site.

\section{REFERENCES}

1) Kemenkes RI [Kementerian Kesehatan RI]. 2013. Guideline for Nutrition Service in Hospital (Pedoman Pelayanan Gizi Rumah Sakit, in Bahasa). Jakarta: Kementerian Kesehatan RI.

2) Aritonang I. Food Service (Penyelenggaraan Makanan, in Bahasa). 2012. Yogyakarta: Jurusan Gizi Poltekkes Yogyakarta.

3) Heryawanti T, Prawirohartono EP, Sudargo T. 2004. The effect of disposable presentation tools on the food waste of patients in the inpatient room of dr. Kariadi Hospital Semarang (Pengaruh alat penyajian disposable terhadap sisa makanan pasien di ruang rawat inap rsup dr. Kariadi Semarang, in Bahasa). J Gizi Klin Indones 1(2): 87-95.

4) Hartwell HJ, Edwards JSA, Symonds C, Hartwell H. 2006. Foodservice in hospital : development of a theoretical model for patient experience and satisfaction using one hospital in the UK National Health Service as a case study. J Foodserv 17: 226-238.

5) Ariyanti V, Widyaningsih EN, Rauf R. 2017. Relationship between sensory characteristics of food with ordinary food waste in inpatients of dr. Soeratno hospital, Gemblong, Sragen Regency (Hubungan antara karakteristik sensorik makanan dengan sisa makanan biasa pada pasien rawat inap RSUD dr. Soeratno, Gemblong, Kabupaten Sragen, in Bahasa). J Kesehat 10(1): 17-25.

6) Puruhita N, Hagnyonowati, Adianto S, Murbawani EA, Ardiaria M. 2014. Overview of food waste and quality of food provided by the nutrition unit of the central public hospital Dr. Kariadi Semarang (Gambaran sisa makanan dan mutu makanan yang disediakan instalasi gizi rumah sakit umum pusat dr. Kariadi Semarang, in Bahasa). JNH 2(3).

7) Nabilah TS. 2015. The relationship between food quality (taste and appearance) and the occurrence of soft food residues in Jasa Kartini Hospital, Tasikmalaya City (Hubungan antara mutu makanan (rasa dan penampilan) dengan terjadinya sisa makanan lunak di RS Jasa Kartini kota Tasikmalaya, in Bahasa). Politeknik Kesehatan Kemenkes Tasikmalaya.

8) Puspita DK, Rahayu RSR. 2011. Factors related to behavior leave food for patients with diabetes mellitus (Faktor-faktor yang berhubungan dengan perilaku menyisakan makanan pasien diit diabetes mellitus, in Bahasa). J Kesehat Masy 6(23): 120-126.

9) Chetboul V, Reynolds BS, Trehiou-Sechi E, Nguyen P, Concordet D, Sampedrano CC, et al. 2014. Cardiovascular effects of dietary salt intake in aged healthy cats: A 2-year prospective randomized, blinded, and controlled study. PLoS One $\mathbf{9}(6)$.

10) Golledge J, Hankey GJ, Yeap BB, Almeida OP, Flicker L,
Norman PE. 2014. Reported high salt intake is associated with increased prevalence of abdominal aortic aneurysm and larger aortic diameter in older men. PLoS One 9(7): 1-6.

11) Suckling RJ, Swift PA. 2015. The health impacts of dietary sodium and a low-salt diet. Clin Med (Northfield Il) 15(6): 585-588.

12) Semedi P, Kartasurya MI, Hagnyonowati. 2013. Relationship between hospital food service satisfaction and food intake with changes in nutritional status of patients (Study in Sunan Kalijaga Regional Hospital, Demak Regency) (Hubungan kepuasan pelayanan makanan rumah sakit dan asupan makanan dengan perubahan status gizi pasien (Studi di RSUD Sunan Kalijaga Kabupaten Demak), in Bahasa). J Gizi Indones 2(1): 32-41.

13) Mohammadifard N, Khaledifar A, Khosravi A, Nouri F, Pourmoghadas A, Feizi A, et al. 2017. Dietary sodium and potassium intake and their association with blood pressure in a non-hypertensive Iranian adult population: Isfahan salt study. Nutr Diet 74(3): 275-282.

14) Ohta Y, Kimura Y, Kitaoka C, Abe I, Kawano Y. 2017. Blood pressure control status and relationship between salt intake and lifestyle including diet in hypertensive outpatients treated at a general hospital. J Clin Exp Hypertens 39(1): 29-33.

15) Sugiura T, Takase H, Ohte N, Dohi Y. 2018. Dietary salt intake is a significant determinant of impaired kidney function in the general population. Kidney Blood Press Res 43(4): 1245-1254.

16) Paruntu OL. 2013. Nutritional status and implementation of dietary food for hospitalized patients at BLU Prof. DR. R.D. Kandou Manado (Status gizi dan penyelenggaraan makanan diet pasien rawat inap di BLU Prof. DR. R.D. Kandou Manado, in Bahasa). Gizi Indones 5(2): 117-126.

17) Gobel SY, Prawiningdyah Y, Budiningsari RD. 2011. The selected menu of rice diit which is served influences the level of satisfaction of VIP patients at the Regional General Hospital of Southeast Sulawesi Province (Menu pilihan diit nasi yang disajikan berpengaruh terhadap tingkat kepuasan pasien VIP di Rumah Sakit Umum Daerah Provinsi Sulawesi Tenggara, in Bahasa). J Gizi Klin Indones 7(3): 136-145.

18) Brooks CJ, Barrett J, Daly J, Lee R, Blanding N, McHugh A, et al. 2017. A community-level sodium reduction intervention, Boston, 2013-2015. Am J Public Health 107(12): 1951-1957.

19) Kawano R, Ishida M, Kimura E, Matsumoto $H$, Arai $H$. 2015. Pilot intervention study of a low-salt diet with monomagnesium di-L-glutamate as an umami seasoning in psychiatric inpatients. Psychogeriatrics 15(1): $38-42$.

20) Zhao X, Yin X, Li X, Yan LL, Lam CT, Li S, et al. 2014. Using a low-sodium, high-potassium salt substitute to reduce blood pressure among Tibetans with high blood pressure: A patient-blinded randomized controlled trial. PLoS One 9(10): e110131.

21) Habiba RA, Adriani M. 2017. Association between depression, intake, and appearance of food with the morning food waste among inpatients (Study at the Islam Hospital Jemursari Surabaya) (In Bahasa). Amerta Nutr 198-208.

22) Fatkhurohman, Lestari YN, Dian Titis Torina. Relationship to changes in standard food portions with food 
waste from holistic hospital patients in 2016 (Hubungan perubahan standar porsi makan dengan sisa makanan pasien rumah sakit holistik tahun 2016, in Bahasa). J Gizi Indones 40(1): 1-8.

23) Mas'ud H, Rochimiwati SN, Rowa SS. 2015. Study of evaluation of patient food scraps and food costs of patients at Dr Tadjuddin Chalid SSR and Makassar City Hospital (Studi evaluasi sisa makanan pasien dan biaya makanan pasien di RSK Dr Tadjuddin Chalid dan RSUD Kota Makassar, in Bahasa). Media Gizi Pangan XIX(1): 91-95.

24) Dehnavi Z, Faghani M, Khorasanchi Z, Bidokhti MS, Norouzy A. 2017. Investigation of the volume of food waste in Qaem and Imam Reza Hospitals in Mashhad, Iran. J Fasting Heal 5(4): 178-183.
25) Ofei KT, Werther M, Thomsen JD, Holst M, Rasmussen HH, Mikkelsen BE. 2015. Reducing food waste in largescale institutions and hospitals: insights from interviews with Danish Foodservice professionals. J Foodserv Bus Res 18(5): 502-519.

26) Sutyawan, Setiawan B. 2013. Food service, food acceptance, and level of intake of superior class boarding students at Pemali Bangka Belitung High School 1 (Penyelenggaraan makanan, daya terima makanan, dan tingkat asupan siswa asrama kelas unggulan SMA 1 Pemali Bangka Belitung, in Bahasa). J Gizi dan Pangan 8(3): 207-214.

27) Spence C. 2017. Hospital food. Spence Flavour 6(3): 114. 